\title{
Policy Alienation, Social Alienation and Working-Class Abstention in Britain, 1964-2010
}

\author{
OLIVER HEATH*
}

\begin{abstract}
This article presents an examination of class-based inequalities in turnout at British elections. These inequalities have substantially grown, and the class divide in participation has become greater than the class divide in vote choice between the two main parties. To account for class inequalities in turnout three main hypotheses - to do with policy indifference, policy alienation and social alienation - are tested. The results from the British context suggest that the social background of political representatives influences the ways in which voters participate in the political process, and that the decline in proportion of elected representatives from working-class backgrounds is strongly associated with the rise of working-class abstention.
\end{abstract}

Keywords: Turnout; class voting; social representation; policy polarization.

In recent years there has been a great deal of concern about declining levels of turnout at elections in Britain. ${ }^{1}$ Much of this research has concentrated on the decline in turnout among young people in particular. ${ }^{2}$ However, young people are not the only social group to have shown a dramatic fall in turnout. In this article I examine the electoral participation of the working class. Although it has been well documented that the strength of class voting has declined in Britain, ${ }^{3}$ it is less well documented that class-based differences in turnout have increased, and that the working class are now much less likely to vote than the middle class.

In 2010 the difference in reported turnout between the working class and salariat was 19 percentage points, compared to less than just 5 percentage points in 1964 . Put into context, the difference in reported turnout between the under-30s and the over-60s in 2010 was 21 percentage points. ${ }^{4}$ Whereas this 'age gap' has received an enormous amount of academic and policy attention, with numerous mobilization initiatives launched to try and get young people more involved in politics, the 'class gap', of a very similar magnitude, has received almost no attention at all. And whereas young people tend to grow into older people, and turnout tends to increase with the transition to adulthood, ${ }^{5}$ working-class people tend to stay working-class, as do their children. In the context of rising inequality and stalled social mobility the 'class gap' in turnout warrants closer attention.

In this article I examine the sources of working-class abstention. I do so with reference to some of the key theories of class voting and turnout. Traditionally, two distinctive approaches have dominated studies on class voting. The first approach holds that political cleavages are

\footnotetext{
* Department of Politics and International Relations, Royal Holloway, University of London, (email: Oliver. Heath@rhul.ac.uk). The author thanks Heinrich Best and Stephan Jahr for sharing data, and Geoffrey Evans, Nicholas Allen, the Editor Robert Johns and the reviewers for their constructive comments and feedback. Further data is available at http://dataverse.harvard.edu/dataverse/BJPolS.

1 See Clarke et al. 2004; Heath 2007; Smets 2012.

2 See Franklin 2004; Sloam 2014.

3 Evans and Tilley 2012a; Evans and Tilley 2012b; Heath 2015.

4 Data from the British Election Studies.

5 Smets 2016.
} 
shaped by 'bottom-up' factors to do with changes in the social structure of the electorate. ${ }^{6}$ According to this 'class heterogeneity' perspective, rising living standards, the spread of affluence and educational expansion have weakened the distinctiveness of social classes and blurred class boundaries, leading to a decline in class voting. ${ }^{7}$ Although this interpretation has been challenged on a number of grounds; ${ }^{8}$ with respect to turnout specifically the blurring of class boundaries would appear ill-equipped to explain in a straightforward way why classes have become more distinctive in terms of their turnout patterns, since if anything educational expansion should increase turnout as citizens now possess the political resources and skills that might help them to deal with the complexities of politics without reliance on party cues. ${ }^{9}$

In recent years there has been a 'fundamental shift' in the study of political participation to acknowledge the critical role of political elites, both in terms of stimulating (or at times, depressing) voter turnout, ${ }^{10}$ and mobilizing (or demobilizing) class divisions. ${ }^{11}$ As Przeworski puts it, 'individual voting behaviour is an effect of the activities of political parties'. ${ }^{12}$ And as Evans and Tilley conclude: strategic moves by political actors are capable of generating pronounced changes in the social bases of party support over relatively short periods of time. ${ }^{13}$ According to this 'top-down' perspective voters do not behave blindly, but respond to the structure of the political choice between the parties they face. The agent of change in this approach is clearly political, rather than social structural - even if political strategy is often shaped, at least in part, by social conditions. ${ }^{14}$

Drawing on this political choice literature I investigate three key hypotheses that may help to shed light on class-based inequalities in turnout. Existing research has shown that contextual factors such as electoral competitiveness, ${ }^{15}$ and policy distinctiveness affect turnout. ${ }^{16}$ Voters are constrained by the electoral choices they are offered, and as Leighley and Nagler observe, from a self-interest perspective it would be more foolish to sit out an election where the choices differ than to sit out one in which the choices are not choices, but echoes of each other. ${ }^{17}$ Previous research has tended to examine the structure of this choice in policy terms, most commonly understood in relation to parties' positions on left-right issues. When there are clear ideological differences between the parties there is greater incentive to vote than when there are only minor differences, in which case it does not matter so much which party wins. In the British context Heath shows that voters' perceptions of how much difference there is between the parties influence much of the temporal variation in turnout over time. ${ }^{18}$

Ideological distinctiveness also has clear resonance for class voting and the political participation of the working class. The rationale for this dates back to Lipset et al.'s early assertion that the working class tend to prefer redistributive policies, and so they vote for parties on the left, whereas the middle class try to resist these claims and so vote for parties on the

${ }^{6}$ See Evans and de Graff (2013) for a review.

${ }^{7}$ See, for example Franklin 1985; Franklin 1992.

${ }^{8}$ Evans and Tilley (2013, p. 112) conclude that this 'structural dissolution' thesis has minimal explanatory power for the decline of class voting in Britain.

9 See Dalton 1984; Dalton 2007.

${ }^{10}$ See Leighley and Nagler 2014.

${ }^{11}$ Evans and Tilley 2012a; Evans and van de Graaf 2013.

${ }^{12}$ Przeworski (1985, pp. 100-1).

${ }^{13}$ Evans and Tilley (2012, p. 159).

${ }^{14}$ See Kitschelt 1994; Kitschelt 1995.

${ }^{15}$ See Cox and Munger 1989.

${ }^{16}$ See Leighley and Nagler 2014.

17 Leighley and Nagler 2014.

${ }^{18}$ Heath 2007. 
right. ${ }^{19}$ Similarly, Przeworski and Sprague state that when parties of the left pursue 'supraclass strategies', some workers will respond by abstaining. ${ }^{20}$ Weakliem and Heath suggest that, in the United States, as the Democrats moved to the centre of the political spectrum, class differences in turnout increased. ${ }^{21}$ Accordingly, if parties differ in their policy outlook on left-right issues the incentives to vote (and vote along class lines) are stronger than if the parties stand for much the same policy outlook.

Recent research has shown that the strength of the class-party association in Britain is associated with policy difference between the two major parties. According to Evans and Tilley, 'when there is ideological convergence the strength of the signals from parties to voters is weakened and the motivation for choosing parties on interest/ideological grounds derived from class position is reduced, and vice versa'. ${ }^{22}$ Although there is some evidence that ideological convergence between the Labour and Conservative parties has reduced the incentives to vote along class lines since the 1970s, it is less clear why ideological convergence should have a greater impact on turnout among the working class than it does among the middle class, and so create unequal turnout patterns.

A useful way for thinking about how parties' policy positions may influence turnout is put forward by Zipp, who conceptualized individuals' distance from candidates in each presidential election as resulting in alienation (the distance between an individual's preferred policy position and the closest candidate's policy position) and indifference (the difference in distance between the respondent's preferred policy position and the policy position of each of the candidates). ${ }^{23}$ According to this perspective individuals will be more likely to vote when offered policy choices that match their preferences more closely, and when parties take more distinctive policy positions. When parties' policy positions are not close to those of individuals, then the resulting alienation of the individuals results in lower probability of voting; and when candidates' policy positions are equally appealing or unappealing to an individual, the resulting indifference results in a lower probability of voting. ${ }^{24}$

In the United States' context Plane and Gershtenson find that individuals are less likely to vote when they feel indifferent to or alienated from candidates' ideological positions. ${ }^{25}$ Using data from the 1988-92 Senate elections, they report that alienation has a greater potential effect on citizens' turnout decisions than indifference. ${ }^{26}$ More recently, Leighley and Nagler show that poorer people in the United States tend to see less difference between the policy platforms of candidates than wealthier people, and are least likely to see candidates as offering meaningful choices on issues. ${ }^{27}$ They argue that the poor cannot respond to policy differences that they do not see, and that turnout among the poor will not increase unless one or both of the major parties offers them a distinctive and compelling choice.

Building on these arguments I examine the extent to which policy representation influences classbased inequalities in turnout in Britain. Thus, in class terms, when the Labour party puts forward a left-wing policy position the working class may be more likely to vote, and when Labour adopts a more right-wing policy agenda the working class may become 'alienated' and so abstain. Early work in the British context has suggested such a possibility. Writing after the 1997 election, Heath

19 Lipset et al. 1954.

20 Przeworski and Sprague (1986, pp. 61-4).

21 Weakliem and Heath 1999.

22 Evans and Tilley (2012a, p. 144).

23 Zipp 1985.

24 See Leighley and Nagler 2014.

25 Plane and Gershtenson 2004.

26 See also Adams, Dow and Merrill 2006.

27 Leighley and Nagler (2014, pp. 141-3). 
and Taylor speculated that Labour's move to the centre may have alienated some working-class voters, and that the working class were less likely to say that the Labour party represented workingclass interests after 1997 than they had done previously. ${ }^{28}$ Denver and Hands report that turnout was particularly low in safe Labour seats, ${ }^{29}$ and more recently, Evans and Tilley show that abstention among groups disadvantaged in several ways - with low education, low income and high unemployment - has increased since 2001, perhaps as a consequence of the perception that Labour is less responsive to the concerns of the working class and the poor. ${ }^{30}$

The idea of indifference and alienation also has clear social implications. A voter's sense of indifference or alienation towards political parties may also be shaped by the extent to which parties represent them socially, as well as politically. In exploring this possibility I draw a distinction between the structure of political choices based on policy or 'substantive' representation and political choices based on social or 'descriptive' representation. ${ }^{31}$ Whereas the political representation of women and ethnic minorities in parliament has been on the increase in Britain over the last few years, the representation of other social groups, particularly the working classes, has been declining. ${ }^{32}$ The number of working-class MPs within the Labour party has shrunk, and the candidates that they put forward for elections are increasingly drawn from a narrow range of middle-class occupations. These changes have had a substantial impact on the relative popularity of the party among working- class voters, even controlling for a host of other factors commonly associated with class voting. ${ }^{33}$ Building on this idea in this article I examine whether social representation also matters for turnout. As Labour has become more 'middle class' has the working class become more alienated from the political process, resulting in higher levels of abstention?

\section{THE SOCIAL REPRESENTATION OF WORKING CLASS MPS}

Politicians often talk about their class backgrounds and many campaigns prominently highlight stories about how candidates were raised in poor or working-class families. ${ }^{34}$ The social class of politicians is featured in political advertising, stump speeches and election leaflets, as well as being fodder for political pundits. ${ }^{35}$ Indeed, political reporting in the media is often highly personalized - making references to politicians' upbringing and family background, ${ }^{36}$ though it is a matter of some debate whether it has become more personalized over time. ${ }^{37}$ As a result, knowledge about candidate characteristics is probably more evenly distributed than the notoriously skewed distribution of policy information. ${ }^{38}$ And whether they realize it or not, people frequently use social class stereotypes to make judgements about others based on class markers like clothing, occupation, accent and behaviour. ${ }^{39}$

${ }^{28}$ Heath and Taylor 1999.

29 Denver and Hands 1997.

${ }^{30}$ Evans and Tilley 2011.

${ }^{31}$ Pitkin 1967.

${ }^{32}$ See Heath 2010.

33 See Heath 2015.

${ }^{34}$ See Carnes and Sadin (2015) on the context of the United States. Recent examples in the British context include Sadiq Khan, who spoke about being the son of a bus driver during the 2016 London mayoral election campaign, and Caroline Flint, who spoke about being raised in a single-parent family on Benefits during the 2015 Labour party deputy leader campaign.

${ }^{35}$ Sadin 2011.

${ }^{36}$ See Langer 2007.

${ }^{37}$ See Karvonen 2010.

${ }^{38}$ See Cutler 2002.

${ }^{39}$ See, for example, Fiske et al. 1999; Giles and Sassoon 1983; Lott and Saxon 2002. 
In recent years a growing body of work has shown, at least as far as voters are concerned, descriptive - or social representation matters, and all else being equal, people with a given social characteristic prefer candidates or leaders who share that characteristic. ${ }^{40}$ As Johnston et al. argue 'the more an agent resembles oneself the more he or she might be expected reflexively to understand and act on one's own interests'. ${ }^{41}$ Indeed, in the American context Carnes presents striking evidence that in the House of Representatives, legislators' class backgrounds have an independent effect on how they vote on economic policies, especially on the issues seen as most important to the material welfare of working-class Americans. ${ }^{42}$ More generally, sociodemographic dissimilarity with a political figure tends to decrease a voter's expected utility from the election of that person. ${ }^{43}$ Gathering information on candidates' and parties' policy positions and coming up with an opinion of one's own is a more costly activity than observing the social characteristics of candidates and party leaders. ${ }^{44}$ The social background of politicians thus offers a 'low-information short-cut to estimating a candidate's policy preferences . . . because the voter observes the relationship between these traits and real-life behavior as part of his daily experience'. ${ }^{45}$

Evidence in the British context suggests that the class background of candidates sends particularly strong social signals to voters. For example, Campbell and Cowley ran a series of survey experiments designed to investigate the British public's reactions to wealthy (or not so wealthy) candidates. ${ }^{46}$ They conclude that everyone seemed put off by wealthy candidates, but that the working class are put off more, and the effects are strongest when it comes to the candidate's perceived approachability. In addition, Cowley reports that working-class respondents gave more support to the idea of increasing the number of working-class MPs in parliament than women did to increasing the number of women MPs. ${ }^{47}$

It has long been recognized that citizens' images of the social group character of parties affects partisanship. ${ }^{48}$ The mere awareness of an out-group is sufficient to stimulate in-group favouritism, and the possibility of social comparison generates 'spontaneous' intergroup competition. ${ }^{49}$ Social cues can thus be an incredibly powerful source of identification. In a series of classic experiments on group identity, Tafjet and Tuner present evidence that as long as minimal conditions existed for in-group identification, subjects were prepared to give relatively less to themselves when the award (either in points or money) was to be divided between self and an anonymous member of the in-group, as compared with dividing with an anonymous member of the out-group. ${ }^{50}$ The implications of this is that social identification can over-ride material self-interest. Indeed, the idea that social similarity effects judgements and behaviour has a long history in the social psychology literature. As far back as 1958 Heider argued that interpersonal similarity promotes a sense of 'belongingness', or closeness. ${ }^{51}$ Accordingly, interpersonal attraction, understanding and trust tends to be greater within than between groups.

40 See Campbell and Cowley 2014.

41 Johnston et al. 1992.

42 Carnes 2012.

43 Cutler 2002.

44 See Downs 1957; Popkin 1991.

45 Popkin (1991, p. 63).

46 Campbell and Cowley 2014.

47 Cowley 2013.

48 See Green, Palmquist and Shickler 2002; Miller, Wlezien and Hildreth 1991.

49 Tajfel and Turner (1986, p. 17).

50 Tafjet and Tuner 1986.

51 Heider 1958. 
Subsequent research has found that people tend to like similar others more than dissimilar ones, ${ }^{52}$ and are typically more emotionally invested in close than distant others. ${ }^{53}$

In the 1960s Labour politicians from working-class backgrounds occupied prominent positions within the party and even middle-class politicians, such as Harold Wilson, projected themselves as 'a man of the people' and affected a 'studied working-class accent.' Writing in the Guardian John Mullan reports that 'Wilson's Huddersfield accent was disappearing during the 1940s and 1950s, but mysteriously returned after he became Labour leader in 1963 - a useful contrast to Alec Douglas Home's strangled toff's drawl. ${ }^{, 54}$ Data from the BES in 1964 shows that 54 per cent of respondents described Labour as 'very' working class and 28 per cent as 'fairly' working-class, compared to less than 1per cent who described Labour as 'very' middle-class. The social identity of the party was thus very strong, and the fact that there were so many working-class politicians within the party helped to cement this identity. Labour was not just a party for the working class but was also a party of the working class.

In response to changing social conditions, and the contraction of the traditional working- class sector, the Labour party sought to rebrand its party image in the 1980s and make itself more attractive to the growing middle class: it recruited candidates from middle-class occupations, ${ }^{55}$ and these candidates tended to be parachuted into safe seats, gain promotion quickly, ${ }^{56}$ and occupy visible positions during campaigns. As the number of working-class MPs within the Labour party ranks declined the strength of the working-class social signal that they send voters has weakened. The main parties have thus become far less socially distinctive - and in the eyes of many voters now resemble rival middle-class 'management teams' ${ }^{57}$ As a result, Ford and Goodwin argue that voters have become fed up with the political class as a whole, and the working class in particular have become more alienated from the political system than ever before. ${ }^{58}$

The rise of the so-called 'career politician' - which has received a great deal of attention in the national media - has led to the widespread view that politicians have become increasingly detached from the lives of ordinary voters. Indeed, in recent years (well-off) MPs have frequently displayed an astonishing lack of awareness about what life is like for low-income families and people living on benefits, from claiming that it is impossible to raise a family on an MP's salary of $£ 67,000$ per year, to saying that they would never send their children to a state school. In an outspoken attack Lord O'Donnell, the former head of the Civil Service said there were still 'too many people in politics who just don't get it' and that parliament needed to become more diverse by recruiting 'people who've got more experience of the world, not just being in politics all their lives. ${ }^{59}$ These concerns have also been openly expressed within the Labour party; Hazel Blears, the former Labour cabinet minister, said MPs are out of touch with voters because they have little experience of life outside the 'political bubble' in Westminster, ${ }^{60}$ and Simon Danczuk, one of the few remaining working-class Labour MPs, claimed the party

52 See, for example, Berscheid 1985; Byrne 1971; Byrne, Clore and Worchel 1966; Newcomb 1956.

53 See, for example, Andersen et al. 1998; Aron et al. 1991.

${ }^{54} \mathrm{http}: / /$ www.theguardian.com/theguardian/1999/jun/18/features11.g22

55 Quinn 2004.

56 Allen 2013.

${ }^{57}$ Ford and Goodwin $(2014$, p. 127).

${ }^{58}$ Ford and Goodwin 2014.

${ }^{59} \mathrm{http}: / / \mathrm{www}$.independent.co.uk/news/uk/politics/outoftouch-mps-dont-get-it-says-excivil-service-chief10086249.html

${ }^{60}$ http://www.telegraph.co.uk/news/politics/ed-miliband/11247609/Emily-Thornberry-row-MPs-like-Ed-Milibandare-out-of-touch-says-Hazel-Blears.html 
had been hijacked by a metropolitan elite. ${ }^{61}$ Indeed, in 2012 Labour launched an explicit search for more working-class candidates, to be headed by Jon Trickett, the Shadow Cabinet Office Minister, and its National Executive Committee changed party rules so that selection panels had to take social class into account, as they already do race and sex. ${ }^{62}$

The lack of working-class representation in parliament may have serious implications for how people perceive political parties and participate in the political process. Working-class voters may feel more socially distant from middle-class politicians and consequently more socially alienated from the parties that the MPs represent. If voters attach greater utility to having someone 'like them' in office and feel closer to elected representatives who share their social background, then they may also be more willing to vote and turnout at the polls when there is a party that embodies their social background. To investigate these claims I test three main hypotheses. First, drawing on the idea of 'policy indifference', I examine whether class inequalities in turnout are shaped by the policy distinctiveness of the two main parties. Secondly, drawing on the idea of 'policy alienation', I examine whether class inequalities in turnout are shaped by the policy position of the Labour party. Whereas policy convergence may breed indifference among both the working class and the middle class, the policy position of the Labour party may have a much greater effect on the turnout of the working class, with policy shifts to the right alienating their core working-class support. Thirdly, I also examine whether class inequalities in turnout are shaped by 'social alienation' based on the occupational background of elected representatives. Rather than responding to policy cues, individuals may respond to the social cues that parties send voters. Thus, when a party is full of middle-class politicians, working-class voters may feel more alienated - and socially disconnected from their political representatives and so be less likely to vote. And without a strong social signal voters may also be less able to tell which party best represents their interests, making the calculus of voting more complex.

\section{DATA AND METHODS}

To test these hypotheses I analyse a merged dataset, which combines information on voters, parties' policy positions and the occupational background of MPs. The data comes from three sources. First, to examine the social characteristics and voting behaviour of individuals over time, I use pooled cross-sectional survey data from the British Election Studies, 1964 to $2010 .^{63}$ This series covers thirteen elections and consists of 35,597 interviews. Secondly, to examine policy representation and the policy platforms of the political parties over time, I use Party Manifesto Data from the Manifesto Research Group (MRG). ${ }^{64}$ And thirdly, to examine social representation and the occupational background of MPs, I use data from the Datacube project collated by the EurElite network. ${ }^{65}$

The dependent variable is reported turnout in the last general election. Turnout is measured by whether respondents reported having voted in the election, or not. The base is all those on the electoral register. Although survey estimates of turnout tend to over-report official turnout, ${ }^{66}$ the

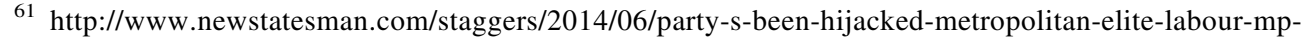
simon-danczuk

62 Cowley 2013.

63 See Clarke et al. (2004) for methodological details.

64 Budge et al. 2001.

65 Best and Cotta 2000.

66 Swaddle and Heath 1989.
} 
BES survey estimates of non-voting closely follow the official data. ${ }^{67}$ The key independent variable is social class. To measure social class, I use a simplified version of the EriksonGoldthorpe seven-class schema, which categorizes people according to their occupation. ${ }^{68}$ Because of concerns over sample size and concerns over how well the skilled and semi-skilled categories are actually distinguished, the higher and lower professional categories and the two working-class categories are collapsed. However, the categories that are collapsed are not strongly distinguishable with respect to their pattern of party choice or level of turnout. Respondents are, therefore, classified into four class categories: Salariat (professional and managerial workers), Petty bourgeois (self-employed, small businessmen and farmers), Routine non-manual, and Manual workers (including supervisors/foremen and skilled and unskilled workers).

Following previous research, policy positions are estimated using party manifesto data. ${ }^{69}$ These data provide a useful indication of party positions since they represent the choices that the electorate faces before each election. Moreover, as the content of party manifestos is often the result of intense intraparty debate, the (MRG) estimates should be reliable and accurate statements about parties' positions at the time of elections. These measures are generally consistent with those from other party positioning studies, such as those based on expert placements, citizen perceptions of parties' positions, and parliamentary voting analyses, which provides additional confidence in the validity and reliability of these estimates. ${ }^{70}$ The MRG measures are based on content analyses of the programmes of the main political parties at every post-war election. The policy statements in each ('quasi-') sentence are classified into fifty-six policy categories over seven policy domains. Following the traditional Laver/Budge methodology, the left-right scores of the various parties can be computed by summing up the percentages of all the sentences in the left category, and subtracting their total from the sum of the percentages of the sentences in the right category. The policy position of the Labour party is simply the sum of these scores. The policy difference between the parties is the difference between these two scores.

To measure the social representation of the working class I use data from the Datacube project collected by the EurElite network. The Datacube is a major study of political representatives in Europe and contains information on the demographic background of elected representatives since $1850 .{ }^{71}$ The data comes from a variety of sources, with the more recent data on Britain between 1964 and 2010 used in this article drawn from the Nuffield Election Series. $^{72}$ The occupational backgrounds of MPs are classified into eleven distinct categories. The working-class composition of the main political parties is calculated as the proportion of MPs in each party from a working-class background (including supervisors/foremen and skilled and unskilled workers). The social difference between the parties is simply the difference between these two scores from the previous election.

\section{Changing Pattern of Working-Class Turnout in Britain}

The first task is simply to examine the association between class and turnout in Britain over time. Figure 1 displays for each social class the probability of its voting in general elections

${ }^{67}$ Evans and Tilley 2011

${ }^{68}$ Erikson and Goldthorpe 1992.

${ }^{69}$ Evans and Tilley 2012a; Ezrow and Xenokasis 2011.

${ }^{70}$ Laver et al. 2003.

${ }^{71}$ See Best and Cotta 2000; Cotta and Best 2007.

72 See Butler and King (1965) on the 1964 election and Criddle (2010) for the latest edition in the series. 


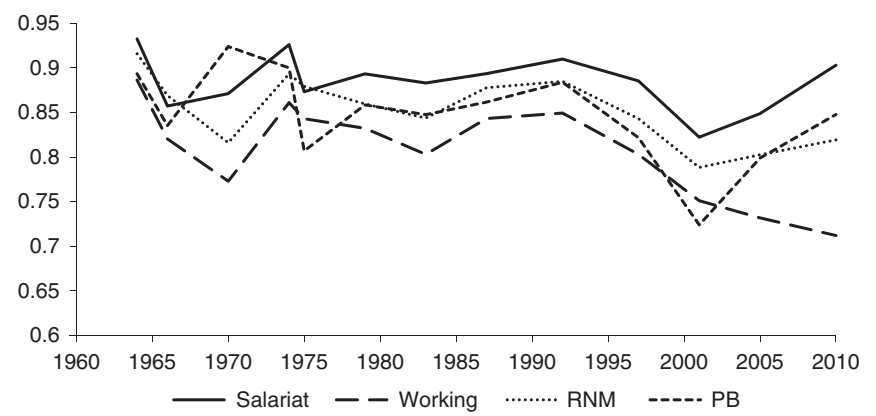

Fig. 1. Reported turnout by class, 1964-2010

Source: BES 1964-2010.

since the 1960s. The working class have always been somewhat less likely to vote than the salariat, and from 1964 to 2001 the difference between the two classes was fairly modest. Turnout bumped along, up and down, but the relative difference in turnout between the working class and the salariat did not change much, and turnout among both groups tended to increase and decrease in tandem. However, since 2001 the turnout between the two classes has sharply diverged, and whereas turnout has been on the increase among the middle classes since the low water mark of 2001, turnout among the working class has continued to fall. In 2010 the difference in reported turnout between the working class and salariat voting was 19 percentage points, compared to less than just 5 percentage points in 1964.

Another way to look at these trends is to consider the relative impact of class on turnout. Figure 2 presents the log odds ratios for the association between class and turnout over time, and for the association between class and vote choice over time (Labour v. Conservative). Although it has been well documented that there has been a decline in the strength of class voting since the 1960s, it has received less attention that there has also been an increase in the effect of class on turnout. ${ }^{73}$ Although the sharpest increase in class inequalities in turnout has taken place since 2001, there has been a pronounced upward trend since 1974, a period which Evans and Tilley also identify as being critical for the start of the weakening impact of class on vote choice. ${ }^{74}$ Moreover, by 2010 the logs odds of class on turnout were of a greater magnitude than they were for the association between class and vote choice. For the first time class is more important as a participatory cleavage than it is as an electoral cleavage.

This represents an important milestone in British political history. Traditionally Britain was regarded as the model of a class society, where class was pre-eminent among the factors used to explain party allegiance. ${ }^{75}$ In comparative terms, the impact of class on vote in Britain was unusually high - and this stood in stark contrast to the United States, where the impact of class on vote choice was unusually small, but the impact of class on turnout was unusually large. ${ }^{76}$ Whereas discussion of class inequality and politics in the United States has long been concerned about the issue of participatory equality, ${ }^{77}$ this issue has not tended to receive much attention in Britain.

73 However, see Evans and Tilley (2011).

74 Evans and Tilley 2012a.

75 Butler and Stokes 1974.

76 See Weakliem and Heath 1999.

77 Verba et al. 1995. 


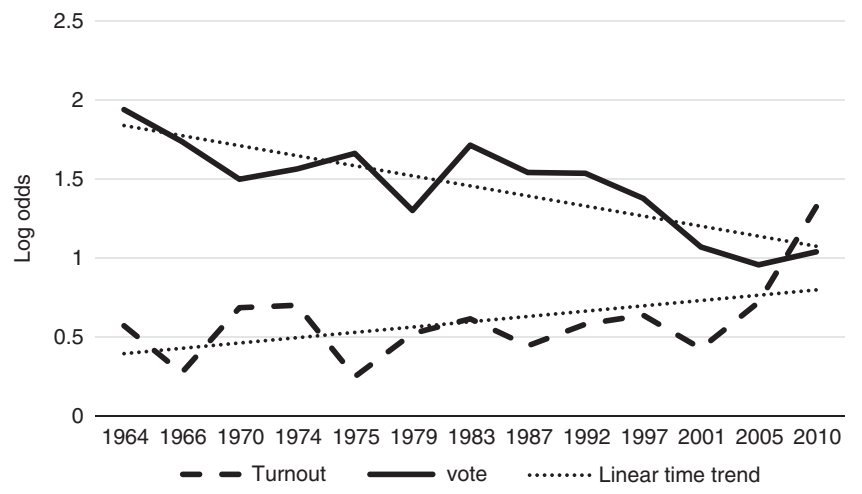

Fig. 2. Impact of class on vote choice and turnout (log odds), 1964-2010

Notes: Log odds are based on a comparison of working class and salariat. Vote choice is based on a comparison of Labour and Conservative.

One other noteworthy feature of Figure 2 is that there is a very strong relationship between the growth of class as participatory cleavage and the decline of class as an electoral cleavage. Moreover, there appears to be a slight lag to this relationship. The association between class voting and class turnout is not particularly strong when both indicators are measured contemporaneously $\left(R^{2}=0.24\right)$; but the association is very strong between the lag of class voting from $t-1$ and class turnout $\left(R^{2}=0.52\right)$. This indicates a process where the decline of class voting is temporally prior to the increase in class inequalities in turnout, and suggests that the two processes may be somehow linked, with a decline in the former leading to an increase in the latter. This provides a further justification to investigate how the factors associated with the decline in class voting have also shaped working-class abstention.

\section{Changing Party Positions on Left-Right Ideology}

One potential reason why the working class may have become disillusioned with voting is, as already discussed, to do with the structure of policy offerings between the two main parties. Figure 3 shows how the main parties in Britain have shifted their left-right policy positions over the last half a century. During the post-war consensus of the 1950s and 1960s there was little ideological difference between the Conservative and Labour positions, though from the mid1950s both parties moved right towards the centre ground. During the 1970s the Labour party moved substantially to the left and stayed there for the best part of twenty years, opening up a clear ideological divide between the two main parties. Since 1992, and in particular since 1994 when Tony Blair took over the leadership of the party there has been a process of policy convergence, with the Labour party moving towards the centre ground, and the Conservatives moving somewhat to the left.

Given that Labour has been moving steadily to the right since the 1992 election, and that turnout among the working class has been steadily declining since then, there is some prima facie evidence to support the idea that Labour's move to the centre ground may have alienated working-class voters and that policy convergence with the Conservatives may also have made the working class indifferent about voting. This combination of indifference and alienation, therefore, could potentially help to account for the increase in turnout inequality. However, this interpretation requires a somewhat selective reading of the data. During the 1960s the Labour 


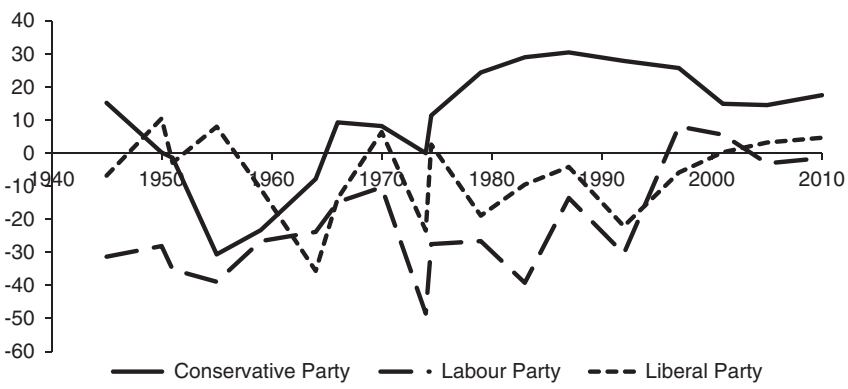

Fig. 3. Left-right positions of parties, 1950-2010

Source: Manifesto Research Group (MRG).

and Conservative parties were also ideologically close to each other and the Labour party also moved towards the right, albeit from a fairly left-wing position, yet working-class abstention was not particularly high. Moreover, during the 1980s, when Labour was clearly on the left and there was also a substantial ideological divide from the Conservatives, working-class abstention was not particularly low. Thus, although policy indifference and policy alienation may help to account for recent changes in the level of working-class abstention, they appear less well equipped to account for the earlier patterns that we observe.

\section{Changing Party Representation of Working-Class MPs}

The next task then is to consider social representation, and examine how the social representation of the working class within the two main parties has changed over time. If the proportion of working-class MPs within the Labour party has declined over time, then the social signals that the party sends voters about what group the party represents will also have become weaker, leading to a hypothesized decline in working-class turnout.

Figure 4 depicts the changes that have taken place in the social background of Labour and Conservative MPs over the last fifty years. The number of MPs with a background in manual work has fallen dramatically. ${ }^{78}$ In 1964 over 37 per cent of Labour MPs came from manual occupational backgrounds. By 2010 this fell to just under 10 per cent. These changes can be traced to institutional changes that were implemented by Kinnock in a bid to modernize the Labour party during the 1980s. As part of an effort to rebrand the party in order to appeal to middle-class voters and distance the party from the working-class radicalism that it had come to be associated with, more and more middle-class candidates were put forward. For example, in 199258 per cent of incumbent Labour candidates thought of themselves as working-class, compared to just 45 per cent of newly selected candidates. ${ }^{79}$

The result of these changes has been a parliament with many fewer voices able to speak from working-class experience, particularly on the Labour side of the House. Such changes in MPs' occupational background have made parliament much less representative of the broader British population, and the Labour party much less representative of the working class, whose interests it was traditionally supposed to represent. As the party has become more socially distant from its core supporters and adopted a more middle-class party image it may be that the working class have become 'socially alienated', and as a result withdrawn from the electoral process.

78 Heath 2010.

79 Data from Pippa Norris's 1992 candidate study (see Norris and Lovenduski 1995). 


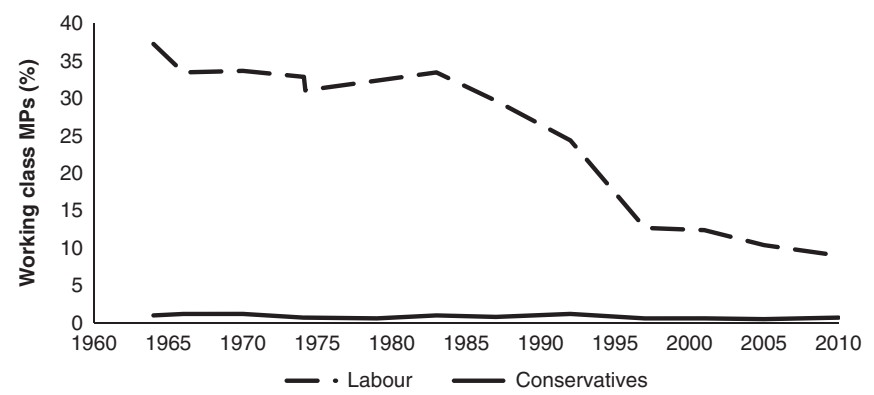

Fig. 4. Working-class MPs in Britain, 1964-2010

Source: Datacube

\section{Turnout and Working-Class Abstention}

To test the hypotheses I link data on policy representation and social representation to pooled cross-sectional survey data, creating a hierarchical dataset in which individuals are nested within elections. I specify a multilevel logit model to estimate how the class-party association varies according to the structure of political choice. At level 1 is the individual survey respondent, and at level 2 is the election. The general model is specified as follows:

$$
\begin{aligned}
\text { TURNOUT }= & f\left(\beta_{0}+\beta_{1} \text { Class }_{i j}+\beta_{2} \text { POLDIF }_{j}+\beta_{3} \text { Class }_{i j} * \text { POLDIF }_{j}+\beta_{4} \text { SOCDIF }_{j},\right. \\
& \left.+\beta_{5} \text { Class }_{i j} * \text { SOCDIF }_{j}\right)
\end{aligned}
$$

where TURNOUT is ( $1=$ voted; $0=$ did not vote $)$ at election $t, \beta_{0}$ is the constant, Class is the occupational background of the voter, POLDIF is the policy difference between the two main parties; Class ${ }^{*} P O L D I F$ is a cross-level interaction between class and policy difference, $S O C D I F$ is the social difference between the two main parties from the previous election; and Class*SOCDIF is a cross-level interaction between class and social difference. I also examine the policy position of the Labour party and include controls for basic demographics, such as age, gender, housing tenure and trade-union membership, which previous research suggests is important for turnout. ${ }^{80}$ Finally, I also control for the expected closeness of the contest, based on the average difference between the top two parties across all published opinion polls in the final month of the campaign. ${ }^{81}$

In order to model the extent to which social classes differ in their voting behaviour I do not control for any attitudinal variables that may be endogenous to class at the individual level or policy difference and social difference at the party level, such as leadership evaluations, economic evaluations or party identification. For example, social differences at the party level may influence party identification at the individual level, and so party identification may be a consequence of social differences (though see robustness checks for Models 6 and 7 in Table 3 below).

Five different models are specified. Model 1 is simply a baseline model of turnout which does not include any class-wise interactions; Model 2 specifies class-wise interactions to test the impact of policy difference on class turnout; Model 3 tests the impact of Labour policy on class turnout; and Model 4 tests the impact of social difference on class turnout. Model 5 tests the

80 Smets and van Ham 2013.

81 Data from 1965 to 1997 come from Heath and Taylor (1999, p. 178)); data from 2001 and 2005 come from Heath (2007) and data from 2010 comes from the UK Polling Report. 
TABle $1 \quad$ Multilevel Logistic Regression Models Predicting Reported Turnout

\begin{tabular}{|c|c|c|c|c|c|c|}
\hline & \multicolumn{2}{|c|}{ Model 1} & \multicolumn{2}{|c|}{$\begin{array}{c}\text { Model 2: } \\
\text { Policy difference }\end{array}$} & \multicolumn{2}{|c|}{$\begin{array}{l}\text { Model 3: } \\
\text { Labour policy }\end{array}$} \\
\hline & $\mathrm{B}$ & S.E. & B & S.E. & B & S.E. \\
\hline Age & $0.063 * * *$ & 0.005 & $0.063 * * *$ & 0.005 & $0.063 * * *$ & 0.005 \\
\hline Age squared & $-0.000 * * *$ & 0.000 & $-0.000 * * *$ & 0.000 & $-0.000 * * *$ & 0.000 \\
\hline Female & 0.016 & 0.035 & 0.014 & 0.035 & 0.015 & 0.035 \\
\hline Trade Union & $0.316^{* * *}$ & 0.042 & $0.314^{* * *}$ & 0.042 & $0.312 * * *$ & 0.042 \\
\hline Housing tenure & $0.423 * * *$ & 0.035 & $0.423 * * *$ & 0.035 & $0.424 * * *$ & 0.035 \\
\hline \multicolumn{7}{|l|}{ Social Class } \\
\hline Routine Non Manual & $-0.17 * * *$ & 0.052 & $-0.256^{* *}$ & 0.099 & $-0.193 * * *$ & 0.058 \\
\hline Petty Bourgeois & $-0.395 * * *$ & 0.073 & $-0.500 * * *$ & 0.144 & $-0.396 * * *$ & 0.084 \\
\hline Working Class & $-0.551 * * *$ & 0.044 & $-0.676 * * *$ & 0.084 & $-0.589 * * *$ & 0.050 \\
\hline Competitiveness & -0.017 & 0.010 & -0.018 & 0.010 & -0.017 & 0.010 \\
\hline Policy Difference & 0.006 & 0.003 & 0.003 & 0.004 & 0.006 & 0.003 \\
\hline \multicolumn{7}{|l|}{ Policy diff by Class } \\
\hline Policy diff by RNM & & & 0.003 & 0.002 & & \\
\hline Policy diff by PB & & & 0.003 & 0.004 & & \\
\hline Policy diff by WC & & & 0.004 & 0.002 & & \\
\hline Labour policy & $-0.016^{* *}$ & 0.005 & $-0.016 * * *$ & 0.005 & -0.010 & 0.006 \\
\hline \multicolumn{7}{|l|}{ Labour policy by Class } \\
\hline Lab policy by RNM & & & & & -0.004 & 0.005 \\
\hline Lab policy by PB & & & & & -0.001 & 0.007 \\
\hline Lab policy by WC & & & & & -0.007 & 0.004 \\
\hline Constant & -0.383 & 0.192 & -0.290 & 0.215 & -0.361 & 0.193 \\
\hline Wald Chi Square & $1067(11)$ & & $1070(14)$ & & $1070(14)$ & \\
\hline Log likelihood & -12270 & & -12269 & & -12269 & \\
\hline
\end{tabular}

Notes: Reference category is salariat. All models contain 12 surveys and 29,483 individuals. $* \mathrm{p}<0.05 ; * * \mathrm{p}<0.01 ; * * * \mathrm{p}<0.005$.

impact of social difference and labour policy simultaneously. The relevant parameter estimates from these models are reported in Tables 1 and 2.

The first model does not contain any class-wise interactions and simply presents a baseline model of turnout. The individual-level variables and election-related variables are all in the expected direction. The policy difference term is significant and in the expected direction individuals are more likely to say they have voted when the two main parties adopt distinctive policy positions, and the political competition term is significant and in the expected direction individuals are more likely to vote when the opinion polls suggest that the result will be close.

However, of more interest from a theoretical point of view, is whether any of the election and party-related variables interact with class in ways which might help to shed light on the increase in working-class abstention. In order to test the policy indifference hypothesis, Model 2 examines the impact that policy difference has on working-class abstention by specifying an interaction term between policy difference and social class. With respect to the working class, the interaction is positive and in the expected direction, but it is imprecisely estimated and does not reach conventional levels of significance (although the $p$ value of 0.075 may charitably be regarded as significant at the 10 per cent level). The findings are, therefore, at best suggestive. Working-class people may be slightly more likely to abstain than the salariat when there is little policy difference between the parties, but in any case the magnitude of the effect is small. 
тавце 2 Multilevel Logistic Regression Models Predicting Reported Turnout

\begin{tabular}{|c|c|c|c|c|}
\hline & \multicolumn{2}{|c|}{$\begin{array}{c}\text { Model 4: } \\
\text { Lagged Social difference }\end{array}$} & \multicolumn{2}{|c|}{$\begin{array}{l}\text { Model 5: } \\
\text { Labour policy }\end{array}$} \\
\hline & $\mathrm{B}$ & S.E. & B & S.E. \\
\hline Age & $0.062 * * *$ & 0.005 & $0.062 * * *$ & 0.005 \\
\hline Age squared & $-0.000^{* * *}$ & 0.000 & $-0.000 * * *$ & 0.000 \\
\hline Female & 0.013 & 0.035 & 0.013 & 0.035 \\
\hline Trade Union membership & $0.299 * * *$ & 0.042 & $0.299 * * *$ & 0.042 \\
\hline Housing tenure & $0.430 * * *$ & 0.035 & $0.431 * * *$ & 0.035 \\
\hline \multicolumn{5}{|l|}{ Social Class } \\
\hline Routine Non Manual & $-0.395 * * *$ & 0.131 & $-0.421 * * *$ & 0.145 \\
\hline Petty Bourgeois & $-0.596 * * *$ & 0.204 & $-0.654 * * *$ & 0.220 \\
\hline Working Class & $-0.892 * * *$ & 0.113 & $-0.903 * * *$ & 0.124 \\
\hline Competitiveness & $-0.013 * *$ & 0.004 & $-0.013 * *$ & 0.004 \\
\hline Policy Difference & 0.000 & 0.002 & 0.000 & 0.002 \\
\hline Lagged Social Difference & $0.017 * * *$ & 0.005 & $0.016 * *$ & 0.006 \\
\hline \multicolumn{5}{|l|}{ Lagged Social diff by Class } \\
\hline Lag Social diff by RNM & 0.010 & 0.005 & 0.012 & 0.007 \\
\hline Lag Social diff by PB & 0.009 & 0.008 & 0.013 & 0.010 \\
\hline Lag Social diff by WC & $0.015^{* * *}$ & 0.004 & $0.015 * *$ & 0.006 \\
\hline Labour policy & $-0.009 * * *$ & 0.003 & $-0.010^{*}$ & 0.005 \\
\hline \multicolumn{5}{|l|}{ Labour policy by Class } \\
\hline Lab policy by RNM & & & 0.003 & 0.006 \\
\hline Lab policy by PB & & & 0.004 & 0.009 \\
\hline Lab policy by WC & & & 0.001 & 0.005 \\
\hline Constant & -0.640 & 0.177 & -0.624 & 0.181 \\
\hline Wald Chi Square & $1162(15)$ & & $1162(18)$ & \\
\hline Log likelihood & -12256 & & -12255 & \\
\hline
\end{tabular}

Notes: Reference category is salariat. All models contain 12 surveys and 29,483 individuals. $* p<0.05 ; * * p<0.01 ; * * * p<0.005$.

We can illustrate this by computing the predicted probabilities of voting at different levels of policy difference. For example, Model 2 predicts that working-class abstention is about 5 percentage points greater than in the salariat when the main parties adopt a distinctive policy platform (based on an MRG difference of 70, compared to the 1983 value of 68). By contrast, the model predicts that working-class abstention is about 9 percentage points greater than the salariat when the parties adopt a similar policy platform (based on an MRG difference of 10, compared to the 2001 value of 9). There is thus some evidence, albeit weak, that the size of the 'class gap' in turnout is conditioned by the policy offerings of the two main parties, and that 'policy indifference' may have had a slightly greater impact on working-class abstention than it has had on middle-class abstention.

In order to test the policy alienation hypothesis, Model 3 examines the policy position of the Labour party and specifies an interaction term with class, while controlling for the level of policy difference between the two parties. The interaction with class is in the expected direction but is once again imprecisely estimated $(p=0.084)$. Nonetheless, there is some indication that working-class people are slightly more likely to abstain than the salariat when the Labour party adopts a more right-wing policy agenda. For example, Model 3 predicts that the difference between someone from the salariat voting and someone from the working class voting is about 
TAвle 3 Robustness Checks: Multilevel Logistic Regression Models Predicting Reported Turnout

\begin{tabular}{|c|c|c|c|c|}
\hline & \multicolumn{2}{|c|}{$\begin{array}{c}\text { Model 6: } \\
\text { Lagged Social difference }\end{array}$} & \multicolumn{2}{|c|}{$\begin{array}{c}\text { Model 7: } \\
\text { Lagged Social difference }\end{array}$} \\
\hline & $\mathrm{B}$ & S.E. & $\mathrm{B}$ & S.E. \\
\hline Age & $0.063 * * *$ & 0.005 & $0.064 * * *$ & 0.005 \\
\hline Age squared & $-0.000 * * *$ & 0.000 & $-0.000 * * *$ & 0.000 \\
\hline Female & 0.010 & 0.035 & 0.009 & 0.035 \\
\hline Trade Union membership & $0.296 * * *$ & 0.042 & $0.297 * * *$ & 0.042 \\
\hline Housing tenure & $0.424 * * *$ & 0.035 & $0.416^{* * *}$ & 0.035 \\
\hline Education & $0.315 * * *$ & 0.067 & $0.315 * * *$ & 0.067 \\
\hline Strength of party identification & & & $0.107 * * *$ & 0.017 \\
\hline \multicolumn{5}{|l|}{ Social Class } \\
\hline Routine Non Manual & $-0.328 *$ & 0.146 & $-0.306^{*}$ & 0.146 \\
\hline Petty Bourgeois & $-0.547 *$ & 0.219 & $-0.530 *$ & 0.219 \\
\hline Working Class & $-0.776 * * *$ & 0.126 & $-0.751 * * *$ & 0.126 \\
\hline Competitiveness & $-0.014 * * *$ & 0.005 & $-0.015 * * *$ & 0.005 \\
\hline Policy Difference & 0.002 & 0.002 & 0.001 & 0.002 \\
\hline Labour Policy & $-0.011 *$ & 0.005 & $-0.011^{*}$ & 0.005 \\
\hline Lagged Social Difference & $0.015^{*}$ & 0.006 & $0.017 * *$ & 0.006 \\
\hline \multicolumn{5}{|l|}{ Lagged Social diff by Class } \\
\hline Lag Social diff by RNM & 0.011 & 0.006 & 0.010 & 0.007 \\
\hline Lag Social diff by PB & 0.012 & 0.009 & 0.011 & 0.009 \\
\hline Lag Social diff by WC & $0.014 *$ & 0.006 & $0.013^{*}$ & 0.005 \\
\hline \multicolumn{5}{|l|}{ Labour Policy by Class } \\
\hline Lab Policy diff by RNM & 0.004 & 0.006 & 0.004 & 0.006 \\
\hline Lab Policy diff by PB & 0.007 & 0.008 & 0.007 & 0.009 \\
\hline Lab Policy diff by WC & 0.002 & 0.005 & 0.002 & 0.005 \\
\hline Constant & -0.766 & 0.189 & -1.004 & 0.192 \\
\hline
\end{tabular}

Notes: Reference category is salariat. Models contain 13 surveys and 30,818 individuals. Missing values are imputed. Number of imputations $=10$. $* p<0.05 ; * * p<0.01 ; * * p<0.005$.

3 percentage points if Labour adopts a very left-wing policy position (based on a CMP score of -40 , compared to the 1983 'longest suicide note in history' value of -39). By contrast workingclass abstention is about 9 percentage points greater than the salariat if Labour adopts a right of centre policy position (based on a MRG score of 10, compared to the 2001 value of 6). These findings suggest that the working class in particular are slightly less likely to vote than the salariat when there is little policy difference between the parties or the Labour party adopts a right of centre policy stance. However, the magnitude of the effect is relatively weak, and the findings are not particularly robust. ${ }^{82}$ Therefore, we should treat the results with caution.

In Table 2 we turn to the social alienation hypothesis. Model 4 tests the impact of lagged social difference on turnout. ${ }^{83}$ The interaction term between social difference and the working class is highly significant $(p=0.001)$ and in the expected direction. Working-class people are significantly less likely than middle-class people to vote when there is little social difference

\footnotetext{
${ }^{82}$ If we specify the interactions simultaneously the results get washed out.

83 The social difference variable is lagged so that it refers to the social composition of the parties at the time of the election (and is therefore based on the intake from the previous election).
} 
between the two parties. The interaction terms between the other class categories and social difference is also in the same direction, perhaps indicating that voters in those classes see working-class MPs as representing 'ordinary people'. However the magnitude of these coefficients is somewhat smaller and less precisely estimated than the coefficient for the working class. Model 4 predicts that working-class abstention is 16 points higher than middleclass abstention if there is no social difference between the parties (based on a difference of 0 , compared to the 2010 value of 8 ). But that working-class abstention is just 3 points higher than middle-class abstention when there are pronounced social differences between the parties (based on a difference of 40, compared to the 1964 value of 36). Class inequalities in turnout appear to respond to the social signals that parties send voters by having MPs from different social backgrounds. As Labour has become more middle-class, the working class in particular have withdrawn from the political process.

These results are robust to the inclusion of the main alternative hypotheses. Model 5 tests policy alienation and social alienation hypotheses simultaneously. ${ }^{84}$ The main results still stand up. ${ }^{85}$ The magnitude of the coefficient for the interaction term between lagged social difference and working-class is stable across models. These findings show that once we take social representation into account the strength of the class-turnout association does not vary by policy alienation (or policy indifference).

We can get a clearer sense of the substantive impact of these findings by plotting the average marginal effects from the interaction between lagged social difference and class. Figure 5 plots the difference that we would predict between a working-class person and a middle-class person voting in a general election at different levels of lagged social difference between the two main parties. When parties are socially similar, Model 5 predicts that the class gap in turnout is close to 16 percentage points. However, when parties are socially distinct and there are many working-class MPs within the Labour party this class gap shrinks to just under 3 percentage points.

As a robustness check Models 6 and 7 introduce a number of additional controls that might influence both turnout and class voting (Table 3). Model 6 controls for education. Data on education are not available for some of the early years, so missing values are imputed. ${ }^{86}$ The expansion of university education has increased the 'cognitive sophistication' of the electorate and as a consequence may have made voters less reliant on either partisan or social cues. ${ }^{87}$ Model 7 also controls for the strength of party identification. It has been well documented that the strength of party identification has declined over time in Britain. Without strong partisan cues and habitual party loyalties those who lack the 'cognitive skills' to deal with politics may be less inclined to vote. ${ }^{88}$ Although the gentrification of the Labour party may have contributed

${ }^{84}$ The results are very similar if the Labour policy term is substituted by the policy difference term.

85 I also substituted the lag variable of social representation (and associated interaction) by a linear time trend variable (results available on request). However, the model with the linear time trend provides a substantially worse fit to the data than the model with the lag of social representation. The difference in the Bayesian information criterion (BIC) between the two models is 12.66. When comparing models, a difference in BIC of 10 corresponds to odds of 150:1 in favour of the social representation model as the better fitting model (Raftery 1995).

86 The surveys in 1964, 1966, 1970 and 1974 do not contain data on education that is straightforward or comparable with later surveys. Rather than dropping these surveys from the analysis, missing values are imputed using the 'stata mi' command with ten imputed datasets. In a separate analysis (not shown) missing values were treated with the EM algorithm with much the same result. The magnitude and significance of the coefficient for education and the interaction between lagged social difference and class are similar across models that impute missing data and exclude missing data (dropping the early surveys from the analysis).

87 Dalton 1984.

88 Dalton 1984; Dalton 2007; Dalton 2012. 


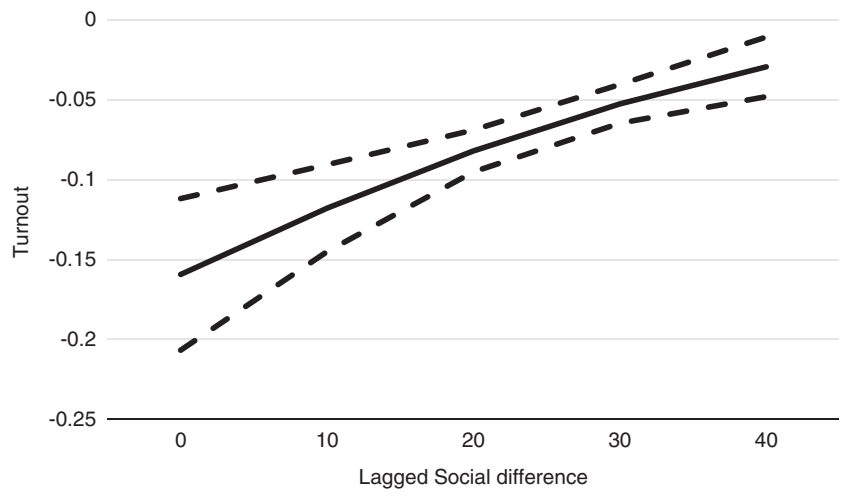

Fig. 5. The class gap in turnout: predicted difference in turnout between the working class and middle class by level of social difference between the parties

Notes: These are predicted probabilities from Model 5 of Table 2, and refer to the difference in turnout between working-class and middle-class people.

- at least in part - to the decline of party identification, Model 7 examines whether social cues still exert an influence on working-class abstention even when we control for partisan cues.

As expected, controlling for education reduces the magnitude of the main effect for class, since the two variables are strongly related (people from working-class backgrounds tend to be less likely to go to university; and people who go to university tend to be less likely to end up in working-class occupations). However, the results of the analysis show that even with these added controls for education and party identification the main findings still hold; and that the magnitude of the class gap in turnout is conditioned by the social distinctiveness of the two main parties. The magnitude of the coefficient is still substantively large and estimated with a high degree of precision $(p=0.018)$.

\section{CONCLUSION}

There is a widespread belief that class has become less important in British politics, and so does not merit as much attention as it once did. This belief is false. While it is certainly true that class divisions are not as evident as they once were in terms of structuring vote choice, this is because class has been pushed outside the political system. Whereas previously the middle class and working class were divided on who to vote for, now they are divided on whether to bother voting at all. This finding is hard to reconcile with the old idea that a decline in class voting signified 'the successful resolution by political systems of deep-seated conflicts of social interests' ${ }^{89}$ The working class have not become incorporated within the political system - they have become more marginalized from it. ${ }^{90}$

Recent studies on the dynamics of class voting have emphasized the political strategies of parties in shaping class divisions. In short, without party strategy that emphasizes or embodies class differences, class position is less likely to be strongly associated with party choice. But this does not mean that class simply disappears. Rather the factors that have contributed to the decline of class as an electoral cleavage have also contributed to the emergence of class as a

89 See van der Eijk et al. (1992, p. 423).

90 See also Ford and Goodwin 2014. 
participatory cleavage. The two processes are inexorably linked. As the Labour party in particular has turned its back on the working class in a bid to appeal to middle-class voters by recruiting more and more candidates from the professional classes, large swathes of the working class have simply stopped voting. Although this strategy has not hurt the Labour party electorally - and may even have paid off in terms of making them more electable in the eyes of middle-class voters - it has done so at the cost of participatory equality.

The results presented in this article indicate that there is a strong over-time relationship between social representation and class inequalities in turnout. This could be because changes in the social background of Labour MPs have made working-class people feel alienated from the party or indifferent about which party wins (or a combination of both). Without a strong social signal voters may also find it harder to decide which party best represents their interests, and so are confronted with an increasingly daunting set of evaluations. The over-time data is unable to shed much light on these different mechanisms, and we would need a different type of study to investigate them. However, there is now a growing body of experimental evidence to support the idea that the class background of candidates influences political attitudes, and that the working class in particular are most 'put-off' by wealthy (middle-class) candidates. ${ }^{91}$ There is also evidence to show that the working class have indeed become increasingly 'alienated' from the political system. ${ }^{92}$ One avenue for further research, therefore, would be to explore whether class and income profiles of candidates also influence more general feelings of political efficacy, which would help to support the link between social alienation and turnout, and whether this link also operates at the constituency level.

As the political choice perspective also makes clear, social divisions in politics are not fixed. And there is no reason why this trend of working-class political exclusion cannot be reversed. There is now a much greater pool of working-class voters who are electorally available and other parties may seek to court their vote. More generally these excluded voters represent fertile territory for populist parties. In Britain there is evidence that the United Kingdom Independence Party (UKIP) has found a way to connect with the disenfranchised working class ${ }^{93}$ and, if these attempts prove successful over time, there is no reason why working-class turnout should not increase again.

\section{REFERENCES}

Adams, James, Jay Dow and Samuel Merrill. 2006. The Political Consequences of Alienation-Based and Indifference-Based Voter Abstention: Applications to Presidential Elections. Political Behavior 28 (1):65-86.

Allen, Peter. 2013. Linking Pre-Parliamentary Political Experience and the Career Trajectories of the 1997 Election Cohort. Parliamentary Affairs 66 (4):685-707.

Andersen, Susan, Noah Glassman and David Gold. 1998. Mental Representations of the Self, Significant Others, and Nonsignificant Others: Structure and Processing of Private and Public Aspects. Journal of Personality and Social Psychology 75:845-61.

Aron, Arthur, Elaine Aron, Michael Tudor and Greg Nelson. 1991. Close Relationships as Including Other in the Self. Journal of Personality and Social Psychology 60:241-53.

Berscheid, Ellen. 1985. Interpersonal Attraction. Pp. 413-84 in Gardner Lindzey and Elliot Aronson, eds, Handbook of Social Psychology. New York: Random House.

91 See Campbell and Cowley 2014.

${ }^{92}$ Ford and Goodwin 2014.

${ }^{93}$ Ford and Goodwin 2014. 
Best, Henreich, and Maurizio Cotta, eds. 2000. Parliamentary Representatives in Europe 1848-2000: Legislative Recruitment and Careers in Eleven European Countries. Oxford: Oxford University Press.

Budge, Ian, Hans-Dieter Klingemann, Andrea Volkens, Judith Bara, and Eric Tanenbaum. 2001. Mapping Political Preferences: Estimates for Parties, Electors, and Governments 1945-1998. Oxford: Oxford University Press.

Butler, David, and Donald Stokes. 1974. Political Change in Britain. London: Macmillan.

Byrne, Don. 1971. The Attraction Paradigm. New York: Academic Press.

Byrne, Don, Gerald Clore and Philip Worchel. 1966. Effect of Economic Similarity-Dissimilarity on Interpersonal Attraction. Journal of Personality and Social Psychology 4:220-24.

Campbell, Rosie, and Philip Cowley. 2014. Rich Man, Poor Man, Politician Man: Wealth Effects in a Candidate Biography Survey Experiment. British Journal of Politics and International Relations 16:56-74.

Carnes, Nicholas. 2012. Does the Numerical Underrepresentation of the Working Class in Congress Matter? Legislative Studies Quarterly 37 (1):5-34.

Carnes, Nicholas, and Meredith Sadin. 2015. The 'Mill Worker's Son' Heuristic: How Voters Perceive Politicians from Working-Class Families - and How They Really Behave in Office. Journal of Politics 77 (1):285-98.

Clarke, Harold, David Sanders, Marianne Stewart and Paul Whitely. 2004. Political Choice in Britain. Oxford: Oxford University Press.

Cotta, Maurizio, and Henreich Best, eds. 2007. Democratic Representation in Europe: Diversity, Change, and Convergence. Oxford: Oxford University Press.

Cowley, Philip. 2013. Why Not Ask the Audience? Understanding the Public's Representational Priorities. British Politics 8 (2):138-63.

Cox, Gary, and Michael Munger. 1989. Closeness, Expenditures, and Turnout in the 1992 United States House Election. American Political Science Review 83 (1):217-31.

Criddle, Byron. 2010. More Diverse, Yet More Uniform: MPs and Candidates. Pp. 306-29 in Philip Cowley and Dennis Kavanagh, eds, The British General Election of 2010. London: Palgrave Macmillan.

Cutler, Fred. 2002. The Simplest Shortcut of All: Sociodemographic Characteristics and Electoral Choice. Journal of Politics 64 (2):466-90.

Dalton, Russell. J. 1984. Cognitive Mobilization and Partisan Dealignment in Advanced Industrial Democracies. Journal of Politics 46:264-84.

Dalton, Russell. J. 2007. Partisan Mobilization, Cognitive Mobilization and the Changing American Electorate. Electoral Studies 26:274-86.

Denver, David, and Gordon Hands. 1997. Turnout. Parliamentary Affairs 50 (4):720-32.

Downs, Anthony. 1957. An Economic Theory of Democracy. New York: Harper and Row.

Erikson, Robert, and John H. Goldthorpe. 1992. The Constant Flux: A Study of Class Mobility in Industrial Societies. Oxford: Clarendon Press.

Evans, Geoffrey, and James Tilley. 2011. The New Class Divide in Turnout: How Labour's Move to the Centre Has Led to the Political Exclusion of the Less Privileged. Paper presented at the EPOP Annual Conference, Exeter, September 2011.

Evans, Geoffrey, and James Tilley. 2012a. How Parties Shape Class Politics: Explaining the Decline of Class Party Support. British Journal of Political Science 42 (1):137-61.

Evans, Geoffrey, and James Tilley. 2012b. The Depoliticization of Inequality and Redistribution: Explaining the Decline of Class Voting. Journal of Politics 74 (4):963-76.

Evans, Geoffrey, and James Tilley. 2013. Ideological Convergence and the Decline of Class Voting in Britain. Pp. 87-114 in Geoffrey Evans and Nan Dirk de Graaf, eds, Political Choice Matters: Explaining the Strength of Class and Religious Cleavages in Cross-National Perspective. Oxford: Oxford University Press.

Evans, Geoffrey, and Nan Dirk de Graaf, eds. 2013. Political Choice Matters: Explaining the Strength of Class and Religious Cleavages in Cross-National Perspective. Oxford: Oxford University Press.

Ezrow, Lawrence, and Georgios Xenokasis. 2011. Satisfaction with Democracy and Parties' Policy Offerings. Comparative Political Studies 44 (9):1152-78. 
Fiske, Susan, Jun Xu, Amy Cuddy and Peter Glick. 1999. (Dis)respecting Versus (Dis)liking: Status and Interdependence Predict Ambivalent Stereotypes of Competence and Warmth. Journal of Social Issues 55 (3):473-89.

Ford, Robert, and Matthew Goodwin. 2014. Revolt on the Right: Explaining Support for the Radical Right in Britain. London: Routledge.

Franklin, Mark. 1985. The Decline of Class Voting in Britain: Changes in the Basis of Electoral Choice, 1964-1983. Oxford: Clarendon Press.

Franklin, Mark. 1992. The Decline of Cleavage Politics. Pp 383-405 in Mark Franklin, Thomas Mackie and Henry Valen, eds, Electoral Change: Responses to Evolving Social and Attitudinal Structures in Western Countries. Cambridge: Cambridge University Press.

Franklin, Mark. 2004. Voter Turnout and the Dynamics of Electoral Competition in Established Democracies Since 1945. Cambridge: Cambridge University Press.

Giles, Howard, and Caroline Sassoon. 1983. The Effect of Speaker's Accent, Social Class Background and Message Style on British Listeners' Social Judgements. Language and Communication 3 (1):305-13.

Green, Donald, Bradley Palmquist and Eric Schickler. 2002. Partisan Hearts and Minds: Political Parties and the Social Identities of Voters. New Haven, Conn. and London: Yale University Press.

Heath, Anthony, and Bridget Taylor. 1999. New Sources of Abstention. Pp. 164-81 in Geoffrey Evans and Pippa Norris, eds, Critical Elections: British Parties and Voters in Long-term Perspective. London: Sage.

Heath, Oliver. 2007. Explaining Turnout Decline in Britain, 1964-2005: Party Identification and the Political Context. Political Behavior 29 (4):493-516.

Heath, Oliver. 2015. Policy Representation, Social Representation and Class Voting in Britain. British Journal of Political Science 45 (1):173-93.

Heider, Fritz. 1958. The Psychology of Interpersonal Relations. Oxford: Wiley.

Johnston, Richard, André Blais, Henry Brady and Jean Crete. 1992. Letting the People Decide: Dynamics of a Canadian Election. Montreal: McGill-Queen's University Press.

Karvonen, Lauri. 2010. The Personalisation of Politics: A Study of Parliamentary Democracies. Colchester: ECPR Press.

Kitschelt, Herbert. 1994. The Transformation of European Social Democracy. Cambridge: Cambridge University Press.

Langer, Ana. 2007. A Historical Exploration of the Personalisation of Politics in the Print Media: The British Prime Ministers (1945-1999). Parliamentary Affairs 60 (3):371-87.

Laver, Michael, Kenneth Benoit and John Garry. 2003. Extracting Policy Positions from Political Texts Using Words as Data. American Political Science Review 97:311-31.

Leighley, Jan, and Jonathan Nagler. 2014. Who Votes Now? Demographics, Issues, Inequality, and Turnout in the United States. Princeton, N.J.: Princeton University Press.

Lipset, Seymour, Paul Lazarsfeld, Allen Barton and Juan Linz. 1954. The Psychology of Voting: An Analysis of Political Behavior. Pp. 1124-175 in Gardner Lindzey, ed., Handbook of Social Psychology. Cambridge, Mass.: Addison-Wesley.

Lott, Bernice, and Susan Saxon. 2002. The Influence of Ethnicity, Social Class, and Context on Judgments about U.S. Women. Journal of Social Psychology 136:481-99.

Miller, Arthur, Christopher Wlezien and Anne Hildreth. 1991. A Reference Group Theory of Partisan Coalitions. Journal of Politics 53 (4):1134-49.

Newcomb, Theodore. 1956. The Prediction of Interpersonal Attraction. American Psychologist 11: 575-586.

Norris, Pippa, and Joni Lovenduski. 1995. Political Recruitment. Cambridge: Cambridge University Press.

Pitkin, Hanna. 1967. The Concept of Representation. Berkeley: University of California Press.

Plane, Dennis, and Joseph Gershtenson. 2004. Candidate's Ideological Locations, Abstention, and Turnout in U.S. Midterm Senate Elections. Political Behavior 26 (1):69-93.

Popkin, Samuel. 1991. The Reasoning Voter. Chicago: University of Chicago Press.

Przeworski, Adam. 1985. Capitalism and Social Democracy. Cambridge: Cambridge University Press. 
Przeworski, Adam, and John Sprague. 1986. Paper Stones: A History of Electoral Socialism. Chicago: University of Chicago Press.

Quinn, Tom. 2004. Electing the Leader: The British Labour Party's Electoral College. British Journal of Politics \& International Relations 6:333-52.

Sadin, Meredith. 2011. Campaigning with Class: The Effect of Candidate Social Class on Voter Evaluations, working paper, University of California, Berkeley.

Sloam, James. 2014. New Voice, Less Equal: The Civic and Political Engagement of Young People in the United States and Europe. Comparative Political Studies 47 (5):663-88.

Smets, Kaat. 2012. A Widening Generational Divide? The Age Gap in Voter Turnout through Time and Space. Journal of Elections, Public Opinion and Parties 22 (4):407-30.

Smets, Kaat. 2016. Revisiting the Political Life-Cycle Model: Later Maturation and Turnout Decline among Young Adults. European Political Science Review 8 (2):225-49.

Smets, Kaat, and van Ham, Carolien. 2013. The Embarrassment of Riches? A Meta-Analysis of Individual Level Research on Voter Turnout. Electoral Studies 32 (2):344-59.

Swaddle, Kevin, and Heath, Anthony. 1989. Official and Reported Turnout in the British General Election of 1987. British Journal of Political Science 19:537-51.

Tajfel, Henri, and John Turner. 1986. The Social Identity Theory of Intergroup Behaviour. Pp. 7-24 in Stephen Worchel and William Austin, eds, Psychology of Intergroup Relations, 2nd edition, Chicago: Nelson-Hall.

UK Polling Report. Available from http://ukpollingreport.co.uk, accessed 10 July 2016.

van der Eijk, Cees, Mark Franklin, Thomas Mackie, and Henry Valen. 1992. Cleavages, Conflict Resolution and Democracy. Pp 406-32 in Mark Franklin, Thomas Mackie and Henry Valen, eds, Electoral Change: Responses to Evolving Social and Attitudinal Structures in Western Countries. Cambridge: Cambridge University Press.

Verba, Sidney, Kay Schlozman and Henry Brady. 1995. Voice and Equality: Civic Voluntarism in American Politics. Cambridge, Mass.: Harvard University Press.

Weakliem, David, and Anthony Heath. 1999. The Secret Life of Class Voting: Britain, France, and the United States since the 1930s. Pp 97-137 in Geoffrey Evans, ed., The End of Class Politics? Class Voting in Comparative Context. Oxford: Oxford University Press.

Zipp, John. 1985. Perceived Representativeness and Voting: An Assessment of the Impact of Choices and Echoes. American Political Science Review 79:50-61. 